\title{
脳梗塞に合併した脳動脈瘤について
}

\author{
青木 伸夫, 加川 瑞夫, 氏家弘 \\ 朝 日 茂樹, 坂 口淳, 喜多村 孝一
}

\section{Incidental Cerebral Aneurysms Associated with Ischemic Cerebrovacular Disease}

Nobuo Aoki, M.D., Mizuo Kagawa, M.D., Hiroshi UjIIE, M.D., Shigeki Asahi, M.D., Jun Sakaguchi, M.D., and Koichi Kitamura, M.D.

Department of Neurosurgery, Neurological Institute, Tokyo Women's Medical College, Tokyo, Japan

\begin{abstract}
Summary : During the past ten years, 583 cases of cerebral infarction were investigated angiographically in our institute. Incidental unruptured aneurysms were demonstrated in 14 cases $(2.4 \%)$. In two cases the aneurysm was clipped to prevent TIA due to microemboli from the aneurysmal dome itself. Three cases with RIND and one case with a minor completed stroke underwent neck clipping; however, cases of RIND with incidental aneurysms on the same side as the ischemic lesion developed cerebral infarction adjacent to the old ischemic area during the post-operative period. Three cases developed subarachnoid hemorrhage in the follow-up period, which ranged from eight months to 2.2 years after ischemic ictus. Two cases were operated on in the acute stage. The outcome was poor due to newly emerged ischemic deficits. Meticulous decision and evaluation one necessary for operative treatment of incidental infarction.
\end{abstract}

\section{はじめに}

脳梗塞に偶然に未破裂脳動脈瘤の発見される頻度は近年 増加し, 脳梗塞軽症例においては脳動脈瘤をいかに取り扱 うべきかという問題が生じている.

今回われわれは，脳梗塞に合併した未破裂脳動脈瘤14例 について, 未破裂脳動脈瘤の手術群と保存的治療群に分け て臨床経過，予後などを比較検討したので報告する．

\section{対象}

過去 10 年間に当科に入院した脳梗塞は857例であり，脳 血管撮影を施行した症例は583例であった。そのうち未破 裂脳動脈瘤を合併した14例 (2.4\%)を対象とした。脳梗塞 に合併した未破裂脳動脈瘤14例中 6 例は, 脳梗塞慢性期に,
脳動脈瘤 clipping 術を施行した. 8 例は保存的に治療し たが，経過中に 3 例で脳動脈瘤の破裂を認めた。

\section{結果}

\section{1. 手術群について}

脳梗塞に合併した未破裂脳動脈瘤に対して, clipping 術 を施行した 6 症例を Table 1に示す.

症例 1，2 は，頻回の TIA を示し，脳血管撮影上，閉塞 性の血管病変を証明せず，ともに右中大脳動脈分岐部に未 破裂脳動脈瘤を認めた。この未破裂脳動脈瘤は血管撮影上, 石灰化動脈瘤内造影剂貯留などはなく，その最大径はとも に約 $7 \mathrm{~mm}$ であった。しかし TIAの病巣が脳動脈瘤の末 梢血流支配領域と一致しており，脳動脈瘤そのものが, microembolic source であると推測されたため clipping 術 
Table 1 Summary of operative group

\begin{tabular}{|c|c|c|c|c|c|c|c|c|c|}
\hline \multirow{2}{*}{$\begin{array}{l}\text { Case } \\
\text { No. }\end{array}$} & \multirow[b]{2}{*}{ Age } & \multirow[b]{2}{*}{ Sex } & \multirow{2}{*}{$\begin{array}{c}\text { Type } \\
\text { of CVD }\end{array}$} & \multirow{2}{*}{$\begin{array}{l}\text { Neurological } \\
\text { sign or } \\
\text { permanent } \\
\text { deficits }\end{array}$} & \multirow{2}{*}{$\begin{array}{l}\text { Location } \\
\text { of AN }\end{array}$} & \multirow{2}{*}{ Side } & \multicolumn{2}{|c|}{ Angiogram } & \multirow{2}{*}{ Prognosis } \\
\hline & & & & & & & occlusion/stenosis & $\begin{array}{l}\text { arterio- } \\
\text { sclerosis }\end{array}$ & \\
\hline 1 & 48 & $\mathrm{~F}$ & TIA & $\begin{array}{l}\text { L.hemiparesis } \\
\text { attack }\end{array}$ & $\mathrm{MCA}$ & ips. & - & \pm & good \\
\hline 2 & 63 & M & TIA & $\begin{array}{l}\text { L.hemiparesis } \\
\text { attack }\end{array}$ & $\mathrm{MCA}$ & ips. & - & + & good \\
\hline 3 & 40 & M & RIND & $\begin{array}{l}\text { dysarthria } \\
\text { R.hemiparesis }\end{array}$ & ICPC & ips. & L.MCA stenosis & \pm & uncharged \\
\hline 4 & 63 & M & RIND & L.hemiparesis & $\mathrm{MCA}$ & ips. & R.ICA stenosis & H & dead \\
\hline 5 & 65 & M & RIND & motor aphasia & MCA & ips. & L.ICA stenosis & + & poor \\
\hline 6 & 63 & $\mathrm{~F}$ & $\begin{array}{l}\text { minor } \\
\text { c.s. }\end{array}$ & $\begin{array}{l}\text { motor aphasia } \\
\text { R.hemiparesis }\end{array}$ & ICPA & cont. & R.MCA stenosis & + & uncharged \\
\hline
\end{tabular}

Table 2 Summary of conservation group - ruptured cases-

\begin{tabular}{|c|c|c|c|c|c|c|c|c|c|c|c|}
\hline \multirow{2}{*}{$\begin{array}{l}\text { Case } \\
\text { No. }\end{array}$} & \multirow[b]{2}{*}{ Age } & \multirow[b]{2}{*}{ Sex } & \multirow{2}{*}{$\begin{array}{c}\text { Type } \\
\text { of CVD }\end{array}$} & \multirow{2}{*}{$\begin{array}{l}\text { Neurological } \\
\text { sign or } \\
\text { permanent } \\
\text { deficits }\end{array}$} & \multirow{2}{*}{$\begin{array}{c}\text { SAH } \\
\text { H. \& K.'s } \\
\text { grade }\end{array}$} & \multirow{2}{*}{$\begin{array}{c}\text { Location } \\
\text { of } \mathrm{AN}\end{array}$} & \multirow[b]{2}{*}{ Side } & \multicolumn{2}{|c|}{ Angiogram } & \multirow{2}{*}{$\begin{array}{l}\text { operation } \\
\text { (clipping) }\end{array}$} & \multirow{2}{*}{ Prognosis } \\
\hline & & & & & & & & $\begin{array}{c}\text { occlusion/ } \\
\text { stenosis }\end{array}$ & $\begin{array}{l}\text { arterio- } \\
\text { sclerosis }\end{array}$ & & \\
\hline 1 & 46 & $\mathrm{M}$ & minor c.s. & L.hemiparesis & III & $\mathrm{ICPC}$ & ips. & $\begin{array}{l}\text { R. ICA } \\
\text { stenosis }\end{array}$ & + & + & poor \\
\hline 2 & 64 & $\mathrm{M}$ & minor c.s. & L.hemiparesis & II & A. com. & - & $\begin{array}{l}\text { R. MCA } \\
\text { stenosis } \\
\text { L. ICA } \\
\text { stenosis }\end{array}$ & ++ & + & poor \\
\hline 3 & 69 & $\mathrm{~F}$ & minor c.s. & L.hemiparesis & II & ICPC & ips. & $\begin{array}{l}\text { R. MCA } \\
\text { stenosis }\end{array}$ & $H$ & - & poor \\
\hline
\end{tabular}

を施行した，術後経過は良好で，TIAの再発はみられな かった.

症例 3,4,5 では脳血管撮影で，内頸動脈または中大脳 動脈に軽度の狭窄を認めたが脳梗塞の臨床形態が RIND であり，十分な日常生活能力 (ADL)を有していたため, clipping 術を施行した。症例 6 は, minor completed strokeであったが，脳動脈瘤の部位が梗塞巣と反対側であ り, 脳動脈瘤径が $10 \mathrm{~mm}$ を越えていたので, clipping 術を 施行した，手術は正常血圧下で，また temporary clip は使 用せずに行ったが, 症例 4,5 においては術後経過観察中 に狭窄部位の脳梗塞の再発を認めた。

\section{2. 未破裂脳動脈瘤保存的治療群について}

保存的に経過を追跡した 8 例中，3 例 (37.5\%)に脳動脈 瘤の破裂を認めた (Table 2)。脳梗塞の発症から破裂までの 期間は 8 か月から 2 年 2 か月であった. 脳梗塞の臨床形態 はすべて minor completed strokeであり，これらの症例 では抗血小板療法はなされていなかった。症例 1,2 は破 裂後 Hunt \& Kosnik's grade $2 ， 3$ にて, 急性期に clipping 術を施行した. しかしこれらの症例はクモ膜下出血 が中程度であったにもかかわらず，狭窄を伴った内頸動脈
および中大脳動脈の灌流域に vasospasm の時期に一致し て新たな梗塞巣の出現，それに伴う神経症状の悪化を認め た。

経過観察中，破裂を認めなかった症例は 5 例であり (Table 3)，平均年齢は67.3歳と高齢であった。これらの症 例では血管撮影上閉塞性病変は多発していた。 そのうち 2 例は，経過中に脳梗塞の再発を起こし，死亡した。

\section{考察}

今回検討した脳梗塞に合併した未破裂脳動脈瘤の頻度は $2.4 \%$ であり ${ }^{1)}$, 剖検例に認められる脳動脈瘤の頻度 $(0.2 \%$ ～％) を越えることはなかった. 脳動脈瘤の部位 は14例中11例で脳梗塞と同側に，2 例は前交通動脈に合併 し，反対側に存在したものは 1 例のみであった.

脳動脈瘤の後天的発生機序については ${ }^{2) 4}$ 動物実験モデ ルおよび多くの臨床報告例から，1）血行力学的因子，2）高 血圧，3）血管壁の脆弱性などが重要な要因であると推測さ れている。しかし，脳梗塞に合併する脳動脈瘤の頻度が高 くないことは, 脳梗塞の基盤に存在する動脈硬化, 高血圧 の合併, 糖尿病の合併, hemodynamics の変動などは脳動 脈瘤の発生要因と容易になりえないことを示唆している. 
Table 3 Summary of conservative group - unruptured cases-

\begin{tabular}{|c|c|c|c|c|c|c|c|c|c|}
\hline \multirow{2}{*}{$\begin{array}{l}\text { Case } \\
\text { No. }\end{array}$} & \multirow[b]{2}{*}{ Age } & \multirow[b]{2}{*}{ Sex } & \multirow{2}{*}{$\begin{array}{l}\text { Type } \\
\text { of CVD }\end{array}$} & \multirow{2}{*}{$\begin{array}{l}\text { Neurological } \\
\text { sign or } \\
\text { permanent } \\
\text { deficits }\end{array}$} & \multirow{2}{*}{$\begin{array}{l}\text { Location } \\
\text { of AN }\end{array}$} & \multirow[b]{2}{*}{ Side } & \multicolumn{2}{|c|}{ Angiogram } & \multirow[b]{2}{*}{ Prognosis } \\
\hline & & & & & & & occlusion/stenosis & $\begin{array}{l}\text { arterio- } \\
\text { sclerosis }\end{array}$ & \\
\hline 1 & 37 & $\mathrm{~F}$ & minor c.s. & L.hemiparesis & ICPC & ips. & R.ICA stenosis & \pm & uncharged \\
\hline 2 & 63 & $\mathrm{~F}$ & minor c.s. & $\begin{array}{l}\text { motor aphasia } \\
\text { R.hemiparesis }\end{array}$ & $\mathrm{ICPC}$ & ips. & L.ICA stenosis & + & uncharged \\
\hline 3 & 65 & $\mathrm{~F}$ & minor c.s. & L.hemiparesis & BA-SCA & ips. & $\begin{array}{l}\text { R.ICA stenosis } \\
\text { BA stenosis }\end{array}$ & H & uncharged \\
\hline 4 & 69 & M & RIND & $\begin{array}{l}\text { transient } \\
\text { L.hemiparesis }\end{array}$ & A. com. & - & $\begin{array}{l}\text { L.MCA occlusion } \\
\text { R.ICA stenosis } \\
\text { BA stenosis }\end{array}$ & $H+$ & dead \\
\hline 5 & 72 & $\mathrm{~F}$ & major c.s. & $\begin{array}{l}\text { motor aphasia } \\
\text { R.hemiparesis }\end{array}$ & ICPC & ips. & $\begin{array}{l}\text { L.ICA stenosis } \\
\text { R.ICA stenosis }\end{array}$ & H+ & dead \\
\hline
\end{tabular}

一般に諸家の報告によると, incidental な脳動脈瘤の破 裂頻度は 1 〜 \%/年とされているが, われわれの症例で は6.8\%/年と高率であった。

未破裂脳動脈瘤の破裂と最も正の相関を示すのは動脈瘤 の大きさである．Wieber $ら^{7)}$ の130例に及ぶ未破裂脳動脈 瘤症例の検討によると, その大きさが $10 \mathrm{~mm}$ 以下で停止し たときには破裂の可能性はきわめて低いと報告している. しかしわれわれの例では 1 例を除きすべて動脈瘤の大きさ は $10 \mathrm{~mm}$ 以下であった。

これらのことより，脳梗塞に合併した脳動脈瘤は，incidental な脳動脈瘤とは異なり破裂しやすいと考えられた. 基礎疾患としての高血圧, 閉塞性病変による血流動態の異 常，片麻痺などによる精神的および肉体的 stress が脳動脈 瘤の破裂を促す要因になっていると推測される.

われわれの未破裂脳動脈瘤手術症例の中で予後のきわめ て良好であったものは，TIAの 2 例であった. TIAの embolic source として脳動脈瘤が原因となっているとす る315)6) 報告はきわめて少なく，われわれの症例でもその 頻度は全 TIA 78例中 2 例 (2.6\%)であった. Hoffman ら は，血栓源としての脳動脈瘤の脳血管撮影上の特徴を動脈 瘤内の血栓形成所見と，その末梢部の血管閉塞所見から報 告しているが，われわれの症例では脳動脈瘤内血栓形成の 所見は認められなかった. しかし Schunk ら ${ }^{6)}$ は剖検例で dome 内の thrombosis の頻度が脳動脈瘤の大きさと相関 を示し，6１5mmの大きさでは18\%に脳動脈瘤内血栓を 認めたと報告している．すなわち脳動脈瘤は血管撮影上，

異常がなくとも血栓源となる可能性は十分にあると考えら れる。

脳梗塞に合併した脳動脈瘤の手術手技についてはそれが 破裂していかなくともきわめて慎重をきす必要がある。す なわち麻酔中の低血圧を避け, temporary clip は使用せず, 脳の圧排を少なくし，できるだけ動脈瘤近傍の血管には触 れず短時間内に行うことが必要である，脳梗塞例では，慢
性期においても脳血流量の低下が持続しているので，手術 による脳表の露出，圧排によって容易に脳虚血を生じる可 能性があり, 術後は加齢, 脳動脈硬化による脳 compliance の低下のため脳圧排によって生じる脳損傷, 硬膜 下水腫などの可能性を有している.

そのような術中術後に生じた合併症は，手術例の予後を きわめて悪化させるが，われわれの症例では脳梗塞の再発 が morbidityに最も影響を与えていた。

\section{結語}

1)脳梗塞と未破裂脳動脈瘤の合併頻度は2.4\%であり, 脳梗塞経過中に脳動脈瘤の破裂する頻度は6.8\%/年であっ た。

2)脳梗塞に合併した未破裂脳動脈瘤および破裂脳動脈瘤 の予後は, 前者では脳梗塞の再発, 後者ではvasospasm による虚血症状の過度な出現のために不良であった。すな わち脳梗塞に伴った脳動脈瘤では, 閉塞性血管病変が脳動 脈瘤と同側に存在する場合きわめて予後は悪かった。

3) 未破裂脳動脈瘤が TIAの embolic source となってい る症例は全 TIA の $2.6 \%$ であり, その手術予後は良好であ った。

\section{文献}

1) Chason JL, Hindman WM: Berry aneurysms of the circle of Willis. Results of a planned autopsy study. Neurology (Minneap) 8: 41-44, 1958

2) Hashimoto N, Handa H, Nagata I, et al: Experimentally induced cerebral aneurysms in rats. Part 5. Relation of hemodynamics in the circle of Willis to formation of aneurysms. Surg Neurol 13: 41-45, 1980

3) Hoffman WF, Wilson CB, Townsent JJ: Recurrent transient ischemic attacks secondary to a embolizing saccular middle cerebral artery aneurysm. J Neurosurg 51: 103-106, 1979

4) Nagata I, Handa $\mathrm{H}$, Hashimoto $\mathrm{H}$, et al: Experimentally induced cerebral aneurysms in rats. Part 6. Hypertension. Surg Neurol 14: 477-479, 1980 
5) Sasaki T, Kinugawa K, Tanigawa $T$, et al: Embolism from intracranial aneurysms. J Neurosurg 53: 300-304, 1980

6) Schunk H: Spontaneous thrombosis of intracranial aneurysms. Am J Roentgenol 91: 1327-1338, 1964
7) Wiebers DO, Whisnant JP, O'Fallon WM: The natural history of unruptured intracranial aneurysms. N Engl J Med 304: $696-698,1981$ 